\title{
STUDI TINGKAT KERUSAKAN AKIBAT HAMA DAUN PADA TANAMAN MERANTI MERAH (SHOREA LEPROSULA) DI AREAL PERSEMAIAN PT. GEMA HUTANI LESTARI KEC. FENE LEISELA
}

\author{
Martini Wali", Sahria Soamole* \\ *Staf Pengajar FPHUT UNIQRA-Buru, Email: :
}

\begin{abstract}
ABSTRAK
Tujuan dari penelitian ini adalah untuk mengetahui tingkat kerusakan yang disebabkan oleh hama perusak daun pada anakan Meranti di persemaian. Penelitian ini dilakasanakan di areal persemaian IUPHHK PT. Gema Hutani Lestari Kecamatan Fena Leisela Kabupaten Buru yang berlangsung dari bulan Januari-Februari 2014. Metode penelitian menggunakan metode pengamatan pada areal persemaian dengan cara pengambila sampel di setiap bedengan. Bedeng yang digunakan sebagai sampel sebanyak6 bedeng dan tiap bedeng sampel diambil seluruh anakan yang ada pada bedeng tersebut. Pengamatan yang dilakukan hanya berorientasi pada keruskan daun akibat serangan hama. Intesitas kerusakan yang terjadi pada tiap bedeng sampel yang disebabkan hama daun yang tertinggi pada bedeng 5 yaitu 33.34\%, dengan kategori ringan, disusul oleh bedeng 3 yaitu $8.19 \%$, selanjutnya bedeng 6 yaitu 7.35\%, bedeng 2 yaitu $3.18 \%$, bedeng 1 yaitu $0.76 \%$, dan yang terendah pada bedeng 4 yaitu $0.38 \%$. Dari semua intensitas serangan pada tiap bedeng ternyata masih dikategorikan serang ringan.Luas serangan yang diakibatkan hama daun pada tiap bedeng sampel terbesar yaitu bedeng sampel 5 yaitu 33.34\%, disusul bedeng 3 yaitu $28.49 \%$, bedeng sampel 6 yaitu $21.22 \%$, bedeng 1 yaitu 12.73\%, bedeng 2 yaitu 1.22\%, dan luas serangan terendah pada bedeng sampel 4 yaitu $0.91 \%$. Selanjutnya dari hasil penelitian di lapangan di temukan beberapa jenis hama daun yang menyerang tiap bedeng sampel pada meranti di lokasi penelitian yaitu ham jenis Kumbang Puthul.
\end{abstract}

Kata Kunci: Intensitas serangan, Meranti merah, Shorea leprosula

\section{PENDAHULUAN}

Hutan sebagai kesatuan ekosistem yang memberikan pengaruh kepada sumber alam lain. Pengaruh ini melalui tiga faktor lingkungan yang saling berhubungan, yaitu iklim, tanah, dan pengadaan air di berbagai wilayah. Pepohonan hutan juga mempengaruhi struktur tanah dan erosi, jadi pengaruh terhadap pengadaan air di lereng gunung. Hutan yang terletak di kawasan gunung juga, berperan dalam menjaga dan mempertahankan keseimbangan ekologis, karena keberadaan hutan dalam menjaga keseimbangan lingkungan sangat diperlukan. Fungsi hutan dapat memberikan pengaruh positif bagi lingkungan di sekitarnya. Halini berkaitan erat dengan fungsi hutan sebagai fungsi lindung terhadap sumber daya alam yang ada di sekitarnya. Apabila fungsi ini tidak berjalan sebagaimana mestinya, maka potensi terjadinya bencana alam di lingkungan yang ada di bawahnya sulit dihindari, dan potensi kerusakan lingkungan sulit untuk ditanggulangi (Soeriatmadja, 1997).

Permasalahan yang akhir-akhir ini di temui adalah menurunnya fungsi dan potensi hutan seiring dengan makin berkurangnya luasan yang dapat dipertahankan. Berbagai aktivitas manusia dilakukan untuk mengubah fungsi hutan secara ekologis menjadi pemanfaatan lahan secara ekonomis.terhadap beberapa faktor yang menyebabkan kerusakan. 
Umumnya faktor-faktor tersebut berkaitan erat dengan praktek-praktek pembangunan dengan sistem produksi yang tidak berkelanjutan. Semakinbertambahnya jumlah penduduk, maka semakin bertambah kebutuhan terhadap kayu, sehingga bila mengharapkan produksi dari hutan alam saja maka tidak dapat mencukupi kebutuhan tersebut Karena produktivitas hutan alam relatif rendah, oleh karena itu, maka pemerintah Indonesia membangun hutan tanaman industri untuk menjaga keberadaan jenis serta produksi kayu guna melancarkan pembangunan (Djumali,2006).

PT. Gema Hutani Lestari membangun persamaian untuk penanaman lahan kosong atau pengayaan dengan jenis-jenis seperti sengon, uhun, meranti, jabon dan jenis lainnya. Namun pembibitan selalu mengalami kendala dimana lahan-lahan tersebut diserang penyakit atau hama, bila pengelolaannya tidak benarbenar diperhatikan maka target yang ingin dicapai tidak dapat dipenuhi. Hama yang sering menyerang tanaman dan menimbulkan kerusakan biasanya pada daun tanaman meranti adalah hama pemakan daun seperti jenis Cosmoletrus sumatranus (Hehiptera) Arthrosechista hilaris (Lepidoptera), Dhaphanis hypothous (Lepidoptera), semut rangrang (Oecophylla saragellina). Kondisi ini menyebabkan tanaman dipersemaian PT Gema Hutani Lestari tidak akan mencukupi target penanaman yang telah direncanakan. Lahan yang direncanakan untuk di tanami pada kegiatan penanaman adalah pada lahan kosong, pengayaan atau pada kiri kanan jalan. Menyikapi permasalahan ini maka penelitian tentang studi tingkat kerusakan akibat hama daun pada tanaman meranti (Shorea leprosula) perlu dilakukan, dengan tujuan untuk mengetahui seberapa besar tingkat kerusakan yang ditimbulkan akibat serangan hama daun terhadap tanaman meranti di persemaian dan mengetahui jenis-jenis hama yang menyerang dan bagaimana cara pengendaliannya.

\section{METODE PENELITIAN}

\subsection{Lokasi dan Waktu Penelitian}

Penelitian ini dilaksanakan di areal persemaian IUPHHK PT. Gema Hutan Lestari
Kecamatan Fena Leisela Kabupaten Buru, dari bulan Januari sampai Februari 2014.

\subsection{Alat dan Bahan Penelitian}

Alat yang digunakan adalah kamera, alat ukur (meteran), lup (kaca pembesar) dan alat tulis menulis. Adapun bahan yang menjadi objek dalam penelitian ini adalah anakan atau bibit meranti.

\subsection{Metode Penelitian}

Penelitian ini menggunakan metode pengamatan. Pengamatan langsung dengan cara pengambilan sampel di setiap bedengan. Bedengan sampel diambil sebanyak 6 bedeng dan tiap bedeng sampel diambil seluruh anakan yang ada pada bedeng tersebut. Jumlah anakan meranti sebanyak 330 anakan tiap bedeng, sehingga pengamatan yang dilakukan hanya berorientasi pada kerusakan daun akibat serangan hama.

\subsection{Pelaksanaan Penelitian}

Penelitian ini merupakan penelitian lapangan yang dilaksanakan dengan metode pengamatan secara langsung. Data yang diambil meliputi data primer dan data sekunder. Data primer diperoleh dengan cara melaksanakan penelitian langsung di lapangan untuk melihat persemaian meranti dan kerusakan yang ditimbulkan. Data sekunder meliputi data-data penunjang yakni curah hujan, dan lain-lain.

\subsection{Analisis Data}

Adapun analisis data yang digunakan untuk menghitung intensitas kerusakan yang dikemukakan Natawigena (1982) dengan menggunakan rumus :

$$
P=\frac{\sum(\mathrm{M} \times \mathrm{U})}{Z \times N} \times 100 \%
$$

Dimana:

$P=$ Intensitas kurusakan

$\mathbf{M}=$ Jumlah pertanaman dan tiap kategori

$\mathrm{U}=$ Nilai skala dari tiap kategori

$\mathrm{Z}=$ Nilai skala yang ditetapkan tertinggi

$\mathrm{N}$ = Banyaknya tanaman yang diamati

Selanjutnya untuk menghitung luas serangan yang diakibatkan oleh hama pemakan 
daun pada anakan meranti di gunakan rumus yang dikemukakan oleh Natawigena (1982) sebagai berikut :

$$
P=\frac{a}{b} \times 100 \%
$$

Dimana:

$P=$ Luas serangan

Tabel 1. Penentuan Nilai Skala Tiap Kategori Serangan

\begin{tabular}{ccc}
\hline Nilai Skala & Presentasi & Kategori Serangan \\
\hline 0 & - & Normal \\
1 & $>0-25$ & Ringan \\
2 & $>25-50$ & Sedang \\
3 & $>50-75$ & Berat \\
4 & $>75$ & Sangat Berat \\
\hline
\end{tabular}

\section{HASIL DAN PEMBAHASAN}

3.1. Karakteristik dan Kegunaan Meranti Merah

Meranti merah (Shorea leprosula Miq) merupakan salah satu jenis yang populer dalam perdangannya. Berbagai jenis kayu meranti dihasilkan oleh marga shorea dari suku dipterocarpaceae. Sekitar 70 spesies dari marga ini menghasilkan kayu meranti merah. Meranti merah merupakan salah satu kayu komersial terpenting di Asia Tenggara. Kayu ini juga yang paling umum dipakai untuk berbagai keperluan di kawasan Malaysia, kayu ini lazim dipakai sebagai kayu konstruksi, ponil kayu untuk dinding, loteng, sekat tulangan bahkan mebel dan perabot rumah tangga, mainan, peti mati dan lain-lain (Takari, 2007). Tanaman kayu keras ini dapat tumbuh cepat. Lingkaran batangnya pada usia 6 tahun biasa mencapai 40$50 \mathrm{~cm}$. Kayunya berwarna merah muda pudar, merah muda kecoklatan, hingga merah tua kecoklatan. Bentuk tajuk tinggi seperti payung dengan sistem percabangan yang khas. Daun meranti letaknya menempel pada batang utama berwarna hijau mengkilap dan tidak lebar dengan batang bebas cabang mencapai $30 \mathrm{~m}$. Mudah diolah dan ringan. Kayu meranti ini termasuk dalam kelas kuat II-IV, dan keawetan kayunya tergolong dalam kelas awet III-IV (Heyne, 1987).

Meranti tumbuh secara alami di Thailan, Kalimantan, Sumatra, Filipina, Malaysia, dan Asia Tengga. Meranti juga telah di internasionalkan di Kalimantan Timur, Brunei, Filipina, dan negara-negara subtropis lainnya.

\section{$a=$ Jumlah bibit yang di serang \\ $\mathrm{b}=$ Jumlah bibit yang diamati}

Dari analisis data yang diperoleh di atas maka untuk mengetahui kategori serangan tiap serangan oleh hama dapat dilihat pada tabel di bawah ini :
Di Indonesia tanaman ini terdapat di pulau Sumatra, Kalimantan, Maluku, dan diketahui bahwa antara tahun 1936-1940, banyak perkebunan meranti yang didirikan di Thailan, Indonesia Timur, serta Kalimantan dan sebagainya wilayah Sumatra dan Malaysia. Kayu meranti merah tua yang lebih berat biasanya digunakan untuk konstruksi sedang sampai berat, balok, kasur, kusen, pintu-pintu dan jendela, papan lantai, geledak jembatan dan lainny. Meranti juga digunakan untuk program reboisasi dan penghijauan karena dapat memperbaiki sifat-sifat fisik dan kamia tanah di bawah tegakan. Hal ini disebabkan karena cabang, ranting dan daun-daun yang lebar mampu meningkatkan kandungan karbon organik tanah (Soerianegara \& Limmens, 2002).

Meranti (Shorea sp) sebagai salah satu jenis kayu primadona dari hutan tropika ini mulai sulit dicari di pasaran, eksploitasi terhadap jenis ini dimasa ekspor log maupun dimasa kini begitu besar sejalan dengan kebutuhan kayu konstruksi yang meningkat. Sementara pengembangan jenis ini lebih banyak mengandalkan regenerasi alam, belum lagi masa berbuahnya yang tidak beraturan dan masa simpan benih yang pendek, menjadi batasan dalam produksi bibit secara berkesinambungan, sebelum teknik propagasi vegetatif berhasil dikembangkan. Potensi hutan tanaman meranti dalam menyerap karbon pun telah dilakukan untuk menjawab isu di atas, melalui pendugaan akumulasi volume kayu dan biomassa tanaman terhadap 7 
jenis meranti pada berbagai tingkat umur dan dengan kemampuan yang bervariasi sesuai jenis dan umur tanaman (Heriansyah \& Mindawati, 2005).

\subsection{Intensitas Kerusakan}

Berdasarkan hasil penelitian di lapangan menunjukkan bahwa intensitas kerusakan yang disebabkan oleh hama daun pada setiap bedeng sampel yang tertinggi adalah pada bedeng 4 yaitu 33,34\% dengan kategori sedang, disusul oleh bedeng 3 yaitu $8,19 \%$, selanjutnya bedeng 6 yaitu $7,35 \%$, bedeng 1 yaitu 3,19\%, bedeng 2 yaitu $0,76 \%$ dan yang terendah pada bedeng 5 yaitu $0,91 \%$ dengan kategori serangan ringan(Tabel 2).

Tabel 2. Intensitas kerusakan tanaman meranti akibat serangan hama daun di persemaian IUPHHK PT. Gema Hutani Lestari.

\begin{tabular}{ccc}
\hline Bedeng & $\begin{array}{c}\text { Intensitas } \\
\text { Kerusakan (\%) }\end{array}$ & Ketegori Serangan \\
\hline 1 & 3.19 & Ringan \\
2 & 0.76 & Ringan \\
3 & 8.19 & Ringan \\
4 & 33.34 & Sedang \\
5 & 0.91 & Ringan \\
6 & 7.35 & Ringan \\
\hline
\end{tabular}

Dari hasil penelitian menunjukkan bahwa intensitas kerusakan yang terjadi pada bedeng pengamatan dengan kategori sedang untuk bedeng 4 , sedangakan 5 bedeng lainnya mengalami rusak ringan dengan presentasi yang tidak terlalu jauh berbeda untuk masingmasing bedeng pengamatan. Intensitas dan luas serangan hama di persemaian dari jenis tanaman Shorea leprosula, termasuk rusak sedang. Hal ini sejalan dengan Novizan (2003), kerusakan tanaman oleh serangan hama pada suatu areal belum dapat dikatakan sebagai hama dan penyakit jika jumlahnya masih dapat dikendalikan oleh musuh alaminya. Selanjutnya, Mardji (2003) menyatakan bahwa kerusakan yang ditimbulkan secara ekonomis tidak begitu berarti. Ambang ekonomi hama dan penyakit yaitu batasan jumlah tertentu dari populasi organisme pengganggu tanaman yang cukup membuat kerusakan tanaman dan secara ekonomis mulai merugikan. Dari hasil pengamatan belum perlu adanya tindakan untuk pemberantasan tetapi sangat diperlukan untuk pencegahan dengan cara melakukan tindakan silvikultur pada areal persemaian sehingga kesimbangan iklim dan kebersihan areal sekitar persemaian menjadi bersih dari sumber atau tempat untuk berkembang biak menjadi berkurang.
Disamping itu, lokasi penelitian atau pada areal persemaian tersebut selalu dilakukan tindakan silvikultur diantaranya pemupukan, penyiraman, membersihkan tumbuhan pengganggu, pemotongan akar yang keluar dari wadah atau kontiner dan pemberantasan hama dan penyakit. Teknik silvikultur ini bertujuan untuk menekan serangan hama penyakit pada areal persemaian tersebut. Pemberantasan hama dan penyakit hutan merupakan tindakan mengatur populasi hama atau penyakit agar tidak menimbulkan kerusakan yang berarti yang dinilai secara ekonomi. Selanjutnya menurut Indriyanto (2008), pemberantasan hama secara alami maupun secara buatan dapat dilakukan dengan cara melepas musuh-musuh alami dari golongan parasit mapun predator, sedangkan secara buatan diantaranya, secara silvikultur yaitu usaha menciptakan kondisi tegakan hutan agar tidak disukai hama, misalnya mengatur komposisi tegakan, mengatur kerapatan tegakan, dan memilih jenis-jenis pohon yang resisten (tahan) terhadap serangan hama. Secara fisik mekanik, yaitu mengubah kondisi lingkungan sehingga tidak disukai atau tidak cocok untuk hama, menangkap hama dengan tangan atau menggunakan perangkap hama.Secara kimia, pemberantas hamadengan menggunakan bahan kimia seperti penggunaan 
insektisida, nematosida dan lain-lain.Secara sterilisasi hama, yaitu dapat dilakukan cara menekan populasi hama dengan melepaskan hama yang telah disterilkan (dimandulkan), dan pengendalian hama secara terpadu.

Cara pencegahan yang tepat pada areal persemaian dapat dipastikan bahwa tanaman atau semai yang berada pada daerah persemaian tersebut tidak mengalami kerusakan yang lebih besar. Oleh karena itu tindakan preventif atau dengan cara pencegahan perlu dilakukan sedini mungkin. Pencegahan dan pemberantasan penyakit hutan dapat dilakukan dengan prinsip dasar yakni ditujukan langsung kepada penyebabnya. Hal ini dapat dilakukan dengan cara: Sanitasi, yaitu membebaskan lokasi dari penyebab penyakit. Eradikasi, yaitu memusnahkan bersama tanaman inang sama sekali atau memusnakan patogen dengan pestisida. Karantina, yaitu mencegah penyebaran suatu penyakit dari daerah yang satu ke daerah yang lain dengan jalan malarang masuk keluar tanaman atau bagian tanaman yang kemungkinan membawa patogen. Cara biologis, yaitu melepaskan musuh-musuh alamiahnya hingga patogen mati (Suratmo, 2002).

\section{3. Luas Serangan}

Luas serangan yang di akibatkan hama daun pada tiap bedeng sampel terbesar yaitu secara berurutan bedeng sampel 5 dengan persentase serangan $33.34 \%$, bedeng 3 yaitu $28.49 \%$, bedeng 6 yaitu $21.22 \%$, bedeng 1 yaitu $12.73 \%$, bedeng 2 yaitu $1.22 \%$ dan luas serangan terendah pada bedeng 4 yaitu $0.91 \%$. Secara keseluruhan semua serangan yang diakibatkan hama daun pada tiap bedeng sampel dapat disimpulkan bahwa terdapat 4 bedeng sampel dengan kategori serangan ringan dan 2 bedeng sampel dengan kategori serangan sedang. Namun luas serangan masih didominan oleh kategori serangan ringan (Tabel 3).

Beberapa jenis hama yang ditemukan di lapangan dan menyebabkan kerusakan pada daun Meranti di areal pesemaian PT. Gema Hutani Lestari diantaranya yaitu: Kumbang Puthul (Holotrichia helleri), Ulat Penggulung Daun (Lamprosema indicara), dan Belalang (Dissostura SP).

Tabel 3. Luas serangan akibat hama daun yang menyerang tanaman meranti di areal persemaian IUPHHK PT. Gema Hutani Lestari.

\begin{tabular}{cccccc}
\hline Bedeng & $\begin{array}{c}\text { Jumlah } \\
\text { Tanaman }\end{array}$ & $\begin{array}{c}\text { Jumlah Tanaman } \\
\text { yang Terserang } \\
\text { Hama }\end{array}$ & $\begin{array}{c}\text { Jumlah Tanaman } \\
\text { yang Tidak } \\
\text { Terserang Hama }\end{array}$ & $\begin{array}{c}\text { Luas } \\
\text { Serangan } \\
(\%)\end{array}$ & $\begin{array}{c}\text { Kategori } \\
\text { Serangan }\end{array}$ \\
\hline I & 330 & 42 & 288 & 12.73 & Ringan \\
II & 330 & 4 & 326 & 1.22 & Ringan \\
III & 330 & 94 & 236 & 28.48 & Sedang \\
IV & 330 & 3 & 327 & 0.91 & Ringan \\
V & 330 & 110 & 220 & 33.34 & Sedang \\
VI & 330 & 70 & 260 & 21.22 & Ringan \\
\hline
\end{tabular}

1. Kumbang Puthul (Holotrichia hilleri)

Kumbang ini termasuk dalam family Rutelidae dalam bahasa latin yaitu rutilus (merah atau merah emas). Sebutan ini disebabkan karena warna kumbang ini umumnya berkilauan, ada yang biru logam, hijau, coklat kuning, kuning emas, dan kemerahan. Oleh karena itu, kumbang ini merupakan salah satu keluarga serangga yang indah. Kumbang ini diketahui mempunyai ukuran yang bervariasi yakni ada yang besar dan pula yang kecil. Ada yang besar serta kuat dan ada yang ramping.Kumbang ini mempunyai panjang sekitar 12 - $14 \mathrm{~mm}$, dengan panjang uret biasa mencapai $30 \mathrm{~mm}$. Larva(uret) yang masih mudah berwarna putih, sedangkan larva yang tua berwarna agakkekuningan. Larva mempunyai 3 pasang kaki. Bentuk telurnya bulat panjang, berukuran sekitar $2 \mathrm{~mm}$ dan lebar mencapai $1 \mathrm{~mm}$. Kulit telurnya lunak, liat, dan berwana putih. Telur yang baru menetas diletakkan didalam tanah sekitar $5 \mathrm{~cm}$. Uret pada permulaannya hanya memakan humus dan kotoran lainnya. Namun, setelah agak besar, uret memakan akar-akar tanaman yang masih hidup, bahkan kadang memakan kulit batang yang berada dalam tanah sehingga biasa menyebabkan kematian 
tanaman. Sedangkan kumbang dewasanya memakan daun tanaman (Gambar 1a).
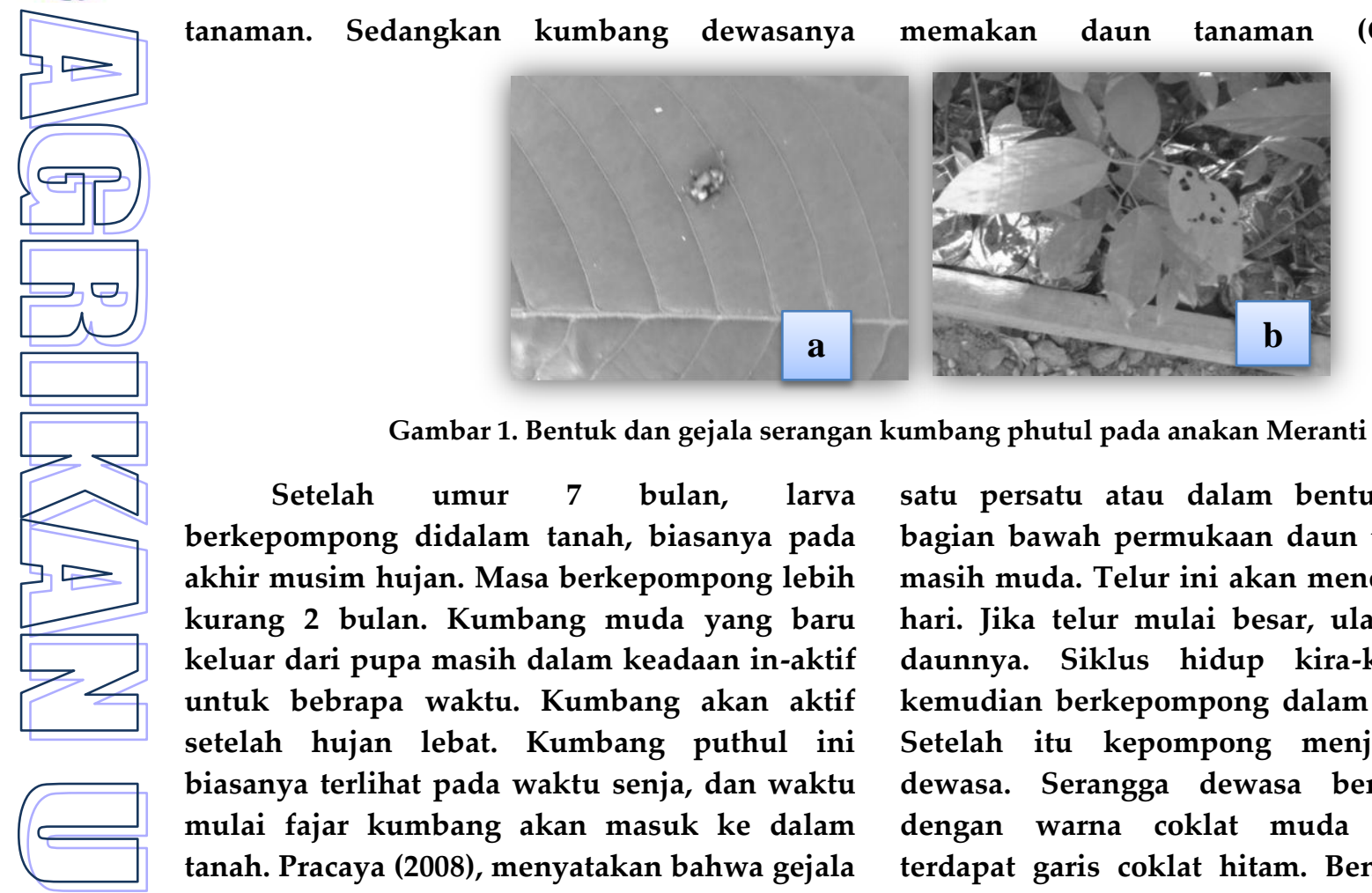

Gambar 1. Bentuk dan gejala serangan kumbang phutul pada anakan Meranti

Setelah umur 7 bulan, larva berkepompong didalam tanah, biasanya pada akhir musim hujan. Masa berkepompong lebih kurang 2 bulan. Kumbang muda yang baru keluar dari pupa masih dalam keadaan in-aktif untuk bebrapa waktu. Kumbang akan aktif setelah hujan lebat. Kumbang puthul ini biasanya terlihat pada waktu senja, dan waktu mulai fajar kumbang akan masuk ke dalam tanah. Pracaya (2008), menyatakan bahwa gejala meranti yang terserang kumbang puthul biasanya terdapat gigitan pada tepi daun dengan bentuk yang tidak rata (Gambar 1b).

\section{Ulat Penggulung Daun (Lamprosema indicara)}

Ulat penggulung daun memiliki ciri yaitu berwarna hijau pucat (kekuningan). Panjang ulat lebih kurang $15 \mathrm{~mm}$. Telurnya diletakan satu persatu atau dalam bentuk barisan di bagian bawah permukaan daun tanaman yang masih muda. Telur ini akan menetas dalam tenggang waktu 4-7 hari. Ulat akan menggulung daun, kemudian berkepompong dalam tabung daun. Pupa (kepompong) berwarna coklat tua dengan ukuran mencapai $10 \mathrm{~mm}$. Telurnya diletakan satu persatu atau dalam bentuk barisan di bagian bawah permukaan daun tanaman yang masih muda. Telur ini akan menetas dalam 4-7 hari. Jika telur mulai besar, ulat penggulung daunnya. Siklus hidup kira-kira 20 hari, kemudian berkepompong dalam tabung daun. Setelah itu kepompong menjadi serangga dewasa. Serangga dewasa berupa ngengat dengan warna coklat muda dan tepinya terdapat garis coklat hitam. Bentangan sayap serangga dewasa (ngengat) berukuran 15-20 $\mathrm{mm}$. Ngengat aktif di malam hari karena tertarik pada cahaya lampu.

Adapun gejala serangan yang disebabkan oleh ulat penggulung daun yaitu ulat dewasa menghubungkan dua tepi daun sebelah atas sehingga daun berbentuk seperti tabung panjang. Tabung tersebut digunakan sebagai tempat tinggal danmemakan jaringan daun tersebut. Gejala serangan di lapangan adalah daun berlubang dan ditemukannya bekas daun yang terserang terdapat garis-garis berwarna putih dan sisa kulit luar atau epidermis (Gambar 2).

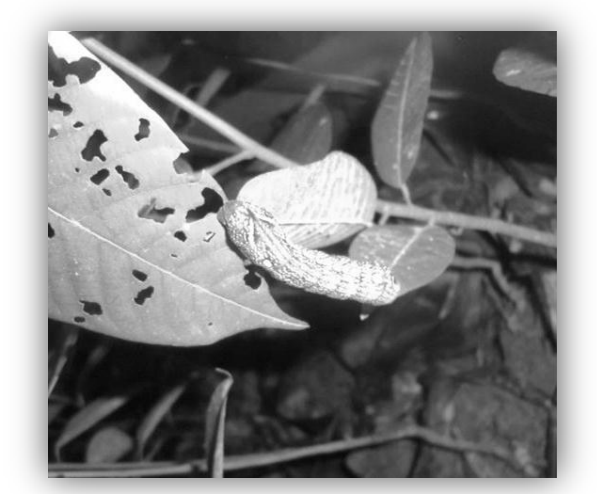

Gambar 2. Bentuk dan gejala serangan ulat penggulung daun pada anakan Meranti

\section{Belalang (Dissostura sp)}

Belalang adalah serangga herbivora dari subordo Caelifera dalam ordo Orthoptera merupakan anggota dari kelas Artrophoda (hewan berbuku-buku) dengan sub kelas Insect. Belalang biasanya dimanfaatkan sebagai 
bahan pangan bagi sebagian masyarakat. Akan tetapi, karena sering merusak tanaman maka biasanya belalang dibunuh dengan menggunakan insektisida. Serangga ini memiliki ciri-ciri khas yaitu memiliki tiga pasang kaki, dan tubuhnya berbuku-buku, memiliki antena yang hampir selalu lebih pendek dari tubuhnya dan juga memiliki ovivositor pendek (gambar 3). Suara yang ditimbulkan beberapa spesies belalang biasanya dihasilkan dengan menggosokan femur belakangnya terhadap sayap depan atau abdomen (disebut stridulasi) atau karena kepakan sayapnya sewaktu terbang, femur belakangnya umumnya panjang dan kuat yang cocok untuk melompat. Serangga ini umumnya bersayap walaupun sayapnya kadang tidak dapat dipergunakan untuk terbang. Belalang betina umunya berukuran lebih besar dari belalang jantan (Borror et al, 1989).

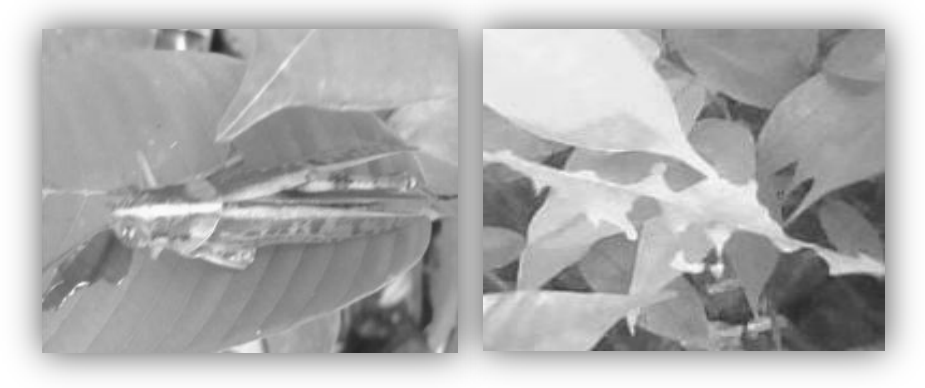

Gambar 3. Bentuk dan gejala serangan belalang pada anakan meranti

\subsection{Pencegahan dan Penanggulangan}

Pentingnya tanaman shorea sebagai salah satu tanaman yang menyelamatkan dunia, karena peranannya dalam mencegah pemanasan global melalaui penyerapan karbon $\left(\mathrm{CO}_{2}\right)$ dalam hal ini tanaman Shorea leprosula Miq. Untuk itu, sangat diperlukan suatu hutan yang terdiri dari individu pohon yang sehat, yang tidak terserang oleh hama dan penyakit. Pencegahan terhadap serangan hama pada persemaian meranti secara dini sangat diperlukan. Hal ini dilakukan dengan tujuan meminimalkan kondisi di lapangan yang menjadi tempat untuk berkembang biak dan beregenerasi hama dan penyakit. Apabila direncanakan untuk perubahan atau perbaikan kualitas dan kuantitas tanaman dapat dilakukan dengan melakukan perekan terhadap tanaman yang resisten atau tahan terhadap serangan hama di lapangan. Hasil penelitian tidak perlu dilakukan pemeberantasan karena tindakan silvikutur yang tepat di lapangan dipandang sudah tepat.

Adapun tindakan teknik silvikultur yang diterapkan antara lain,

a. Pemilihan Lokasi Persemaian

Menurut Indriyanto (2008), mengatakan bahwa faktor-faktor yang perlu dipertimbangkan dalam pemilihan lokasi persemaian, antara lain :
1. Letak lokasi persemaian harus memiliki aksebilitas yang baik, untuk itu harus memperhatikan hal-hal berikut:

- Kemudahan dalam mencari tenaga buruh dan bahan untuk persemaian.

- Keadaan tempat, datar atau paling datar antara tempat-tempat lainnya dalam kawasan hutan yang bersangkutan.

- Mudah dijangkau oleh pekerja atau buruh.

- Ada jalan dari tempat persemaian ke daerah tempat tinggal kerja.

- Letak lokasinya sama jauh terhadap tempat-tempat yang akan ditanami.

2. Kondisi tanah tempat persemaian harus dipilih yang baik dengan memperhatikan kriteria sebagai berikut:

- Tanah subur dengan drainase baik (tidak terlalu basah/kering).

- Tanah harus bersih dari bebatuan dan sisa-sisa tanaman

= Tanah cukup porous dan mudah dikerjakan

3. Persediaan air, untuk persemaian hendaknya persemaian dibangun berdekatan dengan sumber air (mata air) karena persediaan air yang cukup merupakan syarat mutlak persemaian. Serta perlindungan persemaian oleh pengaruh angin, untuk kepentingan 
tersebut, maka pada persemaian dibuat perlindungan angin dengan tanaman jenis pohon yang cepat disekitar lokasi persemaian.

Areal persemaian umumnya dibagi sesuai dengan kegunaannya meliputi lapangan untuk penaburan benih, lapangan untuk tempat penyapihan atau pemindahan anakan, saluran air, jalan, dan gedung-gedung untuk keperluan administrasi.

b. Membersihkan dan Mengelola Tempat Lahan Persemaian

Lahan yang akan digunakan sebgai tempat persemain harus dibersihkan dari tumbuhan. Semua sisa tumbuhan harus dikumpulkan didekat lokasi tersebut. Pembersihan tumbuhan dapat menggunakan pemotong gulma, baik secara manual maupun makanis. Sebaiknya, dihindari menggunakan api atau cara pembakaran. Dalam kegiatan pembersihan lahan karena dapat merusak sifat fisik tanah, juga dapat mengganggu organisme yang ada di lokasi tersebut dan dapat menjadi sumber kebakaran hutan.

\section{c. Membuat Bedengan}

Bedengan berbentuk empat persegi panjang dengan ukuran lebar $1 \mathrm{~m}$, panjang disesuaikan dengan keperluan, tetapi dibiat dengan ukuran panjang 5-10 m, tinggi $10-15 \mathrm{~cm}$ dan permukaan bedengan dibuat agak cembung dengan kecembungan $2 \mathrm{~cm}$ per meter. Bedengan disusun memenjang dari uatara ke selata agar memperoleh sinar matahari pagi secara penuh. Kemudian bagian pinggir bedengan diperkuat dengan bata, bambu, atau papan agar tanah yang berada dalam bedengan tidak terkikis air dan longsor. Di sekelilingi persemaian perlu dipagar untuk menghindari kerusakan yang disebabkan oleh binatang besar atau kecil.

d. Membuat Naungan Pada Persemaian

Beberapa bedengan persemaian perlu diberi naungan dengan payon atap agak miring. Bagian sisi atap yang tinggi di sebelah timur agar sinar matahari pagi dapat masuk secara penuh ke seluruh bedengan dan mengenai bibit. Naungan berguna untuk melindungi benih, kecambah, maupun bibit untuk jenis-jenis pohon yang bersifat tolera. Berguna pula untuk melindungi benih, kecambah, bibit, maupun media tumbuh dari tetasan langsung curah hujan yang kemungkinan dapat merusak. Naugan dapat dibuat dari rusuk bambu,alang-alang, daun kelapa, daun nipa, paranet (sarlon), atau dengan menanam pohon peneduh di persemaian.

\section{e. Menabur Benih}

Penabur benih dapat dilakukan di bedeng tabur, dapat juga langsun disemai dalam tabung bambu berisi media tumbuh semai, dalam pelepah batang pisang, atau dalam kantong plastik berisi media tumbuh semai. Pembuatan persemaian dalam wadahwadah tersebut memudahkan pemindahan di areal penanaman dan mengurangi resiko kerusakan akar. Adapun penaburan benih di bedeng tabur dapat dilakukan dengan dua cara yaitu menabur merata dan menabur dalam larikan.

\section{f. Penyapihan Semai}

Penyapihan semai bertujuan untuk memberikan kemungkinan pertumbuhan agar cabang dan bulu akar yang baik, sehingga apabila semai ditanam di areal penanaman akan diperoleh tanaman yang tumbuh baik dengan presentase cukup tinggi. Pada umumnya, penyapihan semai dikerjakan ketika akar cabang mulai tumbuh dan batangnya mulai mengayu kondisi seperti itu biasanya terjadi pada semai umur 1 minggu hingga 1 bulan setelah benih perkecambahan. Penyapihan semai dilakukan dengan dua cara yairu sebagai berikut :

a. Pada bedeng penyapihan dengan jarak tanam penyapihan rapat untuk jenis pohon yang akan ditanam dengan sistem cabutan.

b. Dalam kantong plastik, polybag, keranjang bambu, ruas bambu, pelepah batang pisang, atau tensopot untuk jenis pohon yang sukar menyesuaikan diri terhadap kondisi tempat tumbuh.

Media tumbuh untuk penyapihan dapat menggunakan tanah atau campuran tanah dengan bahan organik. Bahan baku utama media tumbuh bibit, khususnya untuk penyapihan bibit, berupa tanah (top soil), tetapi tanah saja tidak memenuhi kualifikasi media tumbuh yang baik, sehingga akan lebih baik jika tanah diberi campuran bahan organik. Mencampur tanah dengan bahan organik sebagai salah satu upaya untuk memlihara 
kesuburan media tumbuh bibit, namun sebaiknya bahan organik yang digunakan telah terdekomposisi.

g. Pemeliharaan Persemaian

$=$ Pemupukan

Pemupukan merupakan kegiatan penambahan unsur hara pada media tumbuh tanaman untuk menyeimbangkan unsur hara yang diperlukan terhadap pertumbuhana tanaman. Pupuk yang lazim digunakan untuk persemaian berupa pupuk organik, misalnya pupuk kandang, pupuk kompos, dan bokashi. Akan tetapi, dapat juga menggunakan pupuk anorganik atau pupk buatan misalnya pupuk nitrogen $7-27 \mathrm{~g} / \mathrm{m}^{2}$, pupuk fosfat $5-12 \mathrm{~g} / \mathrm{m}^{2}$, dan pupk kalium 5-12 $\mathrm{g} / \mathrm{m}^{2}$. Pemupukan dapat menggunakan pupuk TPS $1 \mathrm{~g} /$ kantong, Urea 1 g/kantong, dan Kcl 1 g/kantong yang diberikan pada saat mencampur media semai. Pemupukan bibit di persemaian dapat juga menggunakan pupuk majemuk, misalnya NPK dengan dosis $1 \mathrm{~g} /$ kantong pada saat semai berumur 1 bulan setelah disapih, dan dosis 1,5 g/kantong pada saat semai berumur 2 bulan setelah disapih.

- Penyiraman

Penyiraman adalah kegiatan yang bertujuan untuk memberikan unsur air pada tanaman atau media tumbuh. Penyiraman dapat dilakukan sebelum panaburan benih sekali pada bedeng tabur, sedangkan penyiraman setelah benih ditabur dilakukan dengan semprotan halus dua kali sehari (pagi dan sore). Setelah semai disapih, penyiraman dilakukan sekali dalam sehari, yaitu pada pagi hari, sedangkan jika semai sudah besar (umur labih dari 2 bulan) dilakukan 2 atau 3 hari sekali.

- Penyiangan

Penyiangan merupakan kegiatan pembersihan atau pengendalian gulma yang ada pada daerah persemaian. Penyiangan tumbuhan pengganggu pada persemaian dapat dilakukan dengan cara manual yaitu mencabut tumbuhan pengganggu tumbuhan tersebut.

- Pemotongan akar yang keluar dari wadah/kontiner
Pemotongan akar yang keluar dari wadah dilakukan pada saat semai berumur 2 bulan setelah disapih dan dilakukan 1 minggu sebelum diangkut ke areal penanaman. Pemotongan akar semai bertujuan agar akar utama tidak menembus kontine dan memacu pertumbuhan akar bilateral.

= Pengendalian hama

Pengendalian hama merupakan kegiatan pemberatasan hama yang telah menyerang pada tanaman. Kegiatan pengendalian hama yang biasa dilakukan dengan penyemprotan pestisida sesuai dengan dosis yang dianjurkan.

\section{KESIMPULAN}

1. Intensitas keruskan yang terjadi pada tiap bedeng sampel yang di sebabkan hama daun yang tertinggi pada bedeng 4 yaitu $33,34 \%$, dengan kategori sedang, kemudian berturut-turut bedeng 3 yaitu $8,19 \%$, bedeng 6 yaitu $7,35 \%$, bedeng 2 yaitu $0,76 \%$, bedeng 1 yaitu $3,18 \%$, dan yang terendah pada bedeng 4 yaitu $0,38 \%$ dengan kategori serangan ringan. Dari semua intensitas serangan dapat dikategorikan serangan ringan.

2. Luas serangan yang diakibatkan hama daun pada tiap bedeng sampel terbesar yaitu bedeng sampel 5 yaitu $33,34 \%$, disusul bedeng sampel 3 yaitu $28,49 \%$, bedeng sampel 6 yaitu 21,21\%, bedeng sampel 1 yaitu $12,73 \%$, bedeng sampel 2 yaitu $1,22 \%$, dan luas serangan terendah pada bedeng sampel 4 yaitu $0,91 \%$

3. Hama yang menyerang tanaman meranti yang ada di lokasi penelitiuan yaitu; kumbang puthul (Holotrichia helleri), ulatpenggulung daun (Lamprosema indicata) dan belalang (Dissostura $s p$ ).

Untuk menekan kerusakan pada tanaman meranti yang disebutkan hama daun maka perlu dilakukan sistem silvikultur secara terpadu. 


\section{DAFTAR PUSTAKA}

Anonim, 2012. Rencana Karya Pengusahaan HutanIUPHHK. PT. Gema Hutan Lestari.

Borror DJ, Triplehorn CA, Johnson NF. 1989. Pengenalan Pelajaran Serangga. Partosoedjono S. Penerjemah. Brotowidjoyo MD. Penyunting. Gadjah Mada University Pr. Yogyakarta (ID). Terjemahan dari: An Introduction to The Study of Insects. $1083 \mathrm{pp}$

Djumali Mardji, 2006. Ilmu Hama Hutan. Fakultas Kehutanan Universitas Mulawarman. Samarinda.

Djumali. 2006. Ilmu Hama Hutan. Cetakan Pertama Penerbit PT. Bumi Aksara.

Heriansyah I, dan Mindawati, N. 2005. Potensi hutan tanaman marga Shorea dalam menyerap CO2 melalui pendugaan biomassa di Hutan Penelitian Haurbentes. Jurnal Penelitian Hutan dan Konservasi Alam. Departemen Kehutanan. Bogor.

Heyne K. 1987. Tumbuhan Berguna Indonesia Jilid III. Badan Litbang Kehutanan Jakarta. Penerjemah. Yayasan Sarana Wana Jaya. Jakarta (ID).

Indriyanto, 2008. Pengantar Budidaya Hutan. Cetakan Pertama. Penerbit PT. Bumi Aksara. Jakarta. Mardji, D. 2003. Identifikasi dan Penanggulangan Penyakit pada Tanaman Kehutanan. Pelatihan Bidang Perlindungan Hutan di PT ITCI Kartika Utama, Samarinda.

Natawigena, 1982. Pestisida dan Kegunaannya. Universitas Padjajaran. Bandung.

Ngatiman, www.geoogle.com.31/01/2011 - Serangan Hama dan Penyakit pada Bibit Meranti.

Novizan. 2003. Petunjuk Pemakaian Pestisida. Agro Media Pustaka. Jakarta.

Pracaya, 2007. Hama dan Penyakit Tanaman. Cetakan X Edisi Refisi, Penebar Swadaya. Jakarta.

Soeriatmadja, RE. 1997. Ilmu Lingkungan. Penerbit ITB. Bandung.

Suratmo, FG. 2002. Pengendalian Hama Hutan. Bogor: Bagian Perlindungan Hutan Fakultas Kehutanan Institut Pertanian Bogor.

Soerianegara I, Lemmens RHMJ. 1993. Plant resources of south-east asia timber trees: Major commercial timbers. Pudoc Scientific Publishers 5th. Wageningen, Belanda. (NL).

Takari, E. 2007.Kamus VisualTentang Tumbuhan. Penerbit Epsilon Grup. Bandung. 